\title{
Additive influence of extracellular pH, oxygen tension, and pressure on invasiveness and survival of human osteosarcoma cells
}

\author{
Takao Matsubara ${ }^{1}$, Gene R. DiResta ${ }^{2}$, Shigeki Kakunaga ${ }^{3}$, Dasen Li $^{4}$ and John H. Healey \\ ${ }^{1}$ Department of Orthopaedic Surgery, Mie Graduate School of Medicine, Mie, Japan \\ ${ }^{2}$ Department of Chemical and Biomolecular Engineering, Polytechnic Institute of New York University, New York, NY, USA \\ ${ }^{3}$ Department of Orthopaedic Surgery, Osaka National Hospital, Kinki-Block Comprehensive Cancer Center, Osaka, Japan \\ ${ }^{4}$ Musculoskeletal Tumor Center, Peking University People's Hospital, Beijing, China \\ ${ }^{5}$ Orthopaedic Research Laboratory, Department of Surgery, Memorial Sloan-Kettering Cancer Center, New York, NY, USA
}

\section{Edited by:}

Jeffrey Toretsky, Georgetown

University, USA

Reviewed by:

Andrew D. Napper, Nemours

Biomedical Research, USA

Scott C. Borinstein, Vanderbilt

University, USA

*Correspondence:

Takao Matsubara, Department of

Orthopaedic Surgery, Mie Graduate

School of Medicine, 2-174 Edobashi

Tsu City, Mie 5148507, Japan

e-mail: takao-m@clin.medic.

mie-u.ac.jp

\begin{abstract}
Background/Purpose: The effects of chemical and physical interactions in the microenvironment of solid tumors have not been fully elucidated. We hypothesized that acidosis, hypoxia, and elevated interstitial fluid pressure (elFP) have additive effects on tumor cell biology and lead to more aggressive behavior during tumor progression. We investigated this phenomenon using three human osteosarcoma (OS) cell lines and a novel in vitro cell culture apparatus.
\end{abstract}

Materials and Methods: U2OS, SaOS, and MG63 cell lines were cultured in media adjusted to various $\mathrm{pH}$ levels, oxygen tension (hypoxia $2 \% \mathrm{O}_{2}$, normoxia $20 \% \mathrm{O}_{2}$ ), and hydrostatic gage pressure $(0$ or $50 \mathrm{mmHg}$ ). Growth rate, apoptosis, cell cycle parameters, and expression of mRNA for proteins associated with invasiveness and tumor microenvironment (CA IX, VEGF-A, HIF-1A, MMP-9, and TIMP-2) were analyzed. Levels of CA IX, HIF-1 $\alpha$, and MMP-9 were measured using immunofluorescence. The effect of $\mathrm{pH}$ on invasiveness was evaluated in a Matrigel chamber assay.

Results: Within the acidic-hypoxic-pressurized conditions that simulate the microenvironment at a tumor's center, invasive genes were upregulated, but the cell cycle was downregulated. The combined influence of acidosis, hypoxia, and IFP promoted invasiveness and angiogenesis to a greater extent than did $\mathrm{pH}, \mathrm{pO}_{2}$, or elFP individually. Significant cell death after brief exposure to acidic conditions occurred in each cell line during acclimation to acidic media, while prolonged exposure to acidic media resulted in reduced cell death. Furthermore, 48-h exposure to acidic conditions promoted tumor invasiveness in the Matrigel assay.

Conclusion: Our findings demonstrate that tumor microenvironmental parameters - particularly $\mathrm{pH}, \mathrm{pO}_{2}$, and elFP - additively influence tumor proliferation, invasion, metabolism, and viability to enhance cell survival and must be controlled in OS research.

Keywords: osteosarcoma, tumor microenvironment, hypoxia, acidity, elevated interstitial fluid pressure, carbonic anhydrase IX

\section{INTRODUCTION}

Microenvironmental physical-chemical factors - such as $\mathrm{pH}$, oxygen tension $\left(\mathrm{pO}_{2}\right)$, and interstitial fluid pressure (IFP) - influence tumor proliferation, invasion, metabolism, and viability. Extracellular $\mathrm{pH}(\mathrm{pHe})$ and $\mathrm{pO}_{2}$ measured in malignant musculoskeletal tumors are lower than in benign tumors and normal tissues (1). In human osteosarcoma (OS), the eighth most common form of childhood cancer, a study of intraoperative IFP demonstrated a mean IFP of $35.2 \pm 18.6 \mathrm{mmHg}$, which is significantly higher than IFP measured in adjacent normal tissues (2) and is similar to previously reported in vivo IFPs for renal cell and breast carcinomas (3). It is widely recognized that abnormal organization and function of tumor microvasculature create regions within the tumor that are acidotic, hypoxic, and have elevated interstitial fluid pressure (eIFP) $(4,5)$.

Osteosarcoma cell lines grown in vitro under elevated hydrostatic pressure, equivalent to mean in vivo IFP levels measured within central tumor regions, exhibit a more proliferative phenotype than cells grown under typical non-pressurized conditions (2). Tumor cells subjected to hypoxia tend to be more aggressive, displaying increased metastasis, invasion, and mutation (5); in OS specifically, higher levels of hypoxia inducible factor 1-alpha (HIF-1 $\alpha$ ) are associated with high-grade lesions and enhanced tumor cell growth in vitro (6). Acidosis, another 
common microenvironmental characteristic of malignant tumors, has been associated with increased rates of mutation (5) and influences expression of hypoxia-related genes $(7,8)$. While the acidic microenvironment is often attributed to the lactic acid produced through anaerobic metabolism induced by hypoxia, certain investigators have also implicated carbonic acid and, consequently, carbonic anhydrase IX (CA IX), as factors contributing to tumor acidosis $(9,10)$. The effects of each microenvironmental factor is also mediated through altered expression of additional biomarkers, such as hypoxia inducible factor 1 (HIF-1), vascular endothelial growth factor (VEGF), platelet derived growth factor (PDGF), matrix metalloproteinase (MMP) 2 and 9, and tissue inhibitor of metalloproteinase (TIMP) $(9,11-15)$. In addition, these factors have been shown to influence the effectiveness of conventional chemotherapy or radiation-based therapies (11).

While acidosis, hypoxia, and IFP frequently have been examined individually, we hypothesize that these microenvironmental factors exert additive effects on tumor cell biology and may lead to more aggressive or unexpectedly variable behavior during tumor progression and metastasis. Using a novel in vitro cell culture system in which cells can be grown under elevated hydrostatic pressure, we investigated the complex interactions of local $\mathrm{pH}$, $\mathrm{pO}_{2}$, and hydrostatic pressure, individually and in combination, to identify the factor(s) that had the most profound effect on the growth of human OS cell lines and their expression of the proteins that contribute to metastatic potential. Further, because OS is a highly invasive cancer, we analyzed its invasiveness in vitro under acidic and hypoxic conditions. Ostensibly, control of the tumor microenvironment and the consequent altered expression of relevant proteins may allow suppression of aggressive tumor growth and the metastatic potential characteristic of high-grade malignant tumors.

\section{MATERIALS AND METHODS CELL CULTURE}

We used three human OS cell lines (U2OS, SaOS2, and MG63) and, given the propensity for OS to metastasize to lung, we also included one lung carcinoma cell line (H1299) (American Type Culture Collection, Manassas, VA, USA). U2OS and SaOS2 lines were maintained in McCoy's 5A media supplemented with 15\% fetal calf serum (FCS); MG63 was grown in MEM media with 10\% FCS; and H1299 was maintained in RPMI1640 media with $10 \%$ FCS.

\section{MICROENVIRONMENTAL FACTOR COMBINATORIAL STUDY}

These experiments were performed using the OptiCell ${ }^{\circledR}$ culture cassette system (Thermo Scientific, Austin, TX, USA), to which 0 or $50 \mathrm{mmHg}$ hydrostatic pressure (gage) was applied in a manner that we have described previously (2). Briefly, the OptiCell ${ }^{\circledR}$ chamber, which contains two parallel, gas-permeable, cell culturetreated polystyrene membranes that can support monolayer cell growth, was connected to a pressure bag system that was used to apply fluid pressure to the cell culture media. Use of this cell culture system within an incubator allows individual control of hydrostatic pressure, hypoxia, and media $\mathrm{pH}$, to approximate the complex conditions that exist in vivo. The $0 \mathrm{mmHg}$ gage pressure, comparable with conventional cell culture systems, served as the control pressure, while the $50 \mathrm{mmHg}$ (gage pressure) was selected as the elevated hydrostatic pressure, corresponding to a level commonly seen in human and canine OS in vivo and consistent with our previous studies $(2,16,17)$. The culture systems were placed into separate incubators, such that cassettes were exposed to hypoxic $\left(2 \% \mathrm{O}_{2}, 5 \% \mathrm{CO}_{2}\right.$, and $\left.93 \% \mathrm{~N}_{2}\right)$ or normoxic $\left(20 \% \mathrm{O}_{2}, 5 \%\right.$ $\mathrm{CO}_{2}, 75 \% \mathrm{~N}_{2}$ ) conditions. Both incubators were saturated to $100 \%$ humidity and temperature was maintained at $37^{\circ} \mathrm{C}$. Cell culture media was prepared using two buffer systems, a $20 \mathrm{mM}$ piperazine$N, N^{\prime}$-bis (2-ethanesulfonic acid) buffer to formulate the $\mathrm{pH} 6.5$ and 6.8 media, and standard bicarbonate buffer to formulate the $\mathrm{pH} 7.4$ and 7.1 media. $\mathrm{pH}$ was adjusted using $0.1 \mathrm{M} \mathrm{HCl}$.

All cells were seeded at $1.5 \times 10^{5}$ cells/cassette; separate cassettes were provided for each set of conditions. The experimental duration for the cell cycle and cell proliferation studies was $96 \mathrm{~h}$ total, comprising a 24 -h, post-inoculation cell attachment phase, followed by $72 \mathrm{~h}$ of pressurization. The control conditions were $\mathrm{pH}$ 7.4 , normoxic $\mathrm{pO}_{2}$, and $0 \mathrm{mmHg}$. To evaluate the long-term effects of acidic conditions on all cell lines, the cultures were acclimatized, or preconditioned, for 2 weeks in $75 \mathrm{~cm}^{2}$ flasks at $\mathrm{pH} 6.5,6.8,7.1$, or 7.4. They were kept under normoxic $\mathrm{pO}_{2}$ levels and $0 \mathrm{mmHg}$ hydrostatic pressure before transferral into the OptiCell ${ }^{\circledR}$ cassettes and initiation of hydrostatic pressurization and/or hypoxia. At selected intervals, cells within the cassette were released from their membrane using trypsin, spun down, and counted to determine total viable cell count (TVCC). TVCC measured $24 \mathrm{~h}$ after seeding corresponded to the " $0 \mathrm{~h}$ " time point in all studies. Net growth was expressed using the following ratio:

$$
\text { Net growth }=\frac{\text { TVCC (“time point” hour })}{\text { TVCC }(0 \text { hour })}
$$

\section{FLOW CYTOMETRY FOR CELL CYCLE AND APOPTOSIS ANALYSES}

The $\mathrm{H} 1299$ cells, after $72 \mathrm{~h}$ of growth at $37^{\circ} \mathrm{C}$, media $\mathrm{pH} 6.8$, and $2 \% \mathrm{pO}_{2}$, and under $500 \mathrm{mmHg}$ of hydrostatic pressure, were collected, washed with cold PBS, and fixed in $70 \%$ methanol at $4^{\circ} \mathrm{C}$. The U2OS cells, cultured for $72 \mathrm{~h}$ at $37^{\circ} \mathrm{C}$; media $\mathrm{pH} 7.4,7.1,6.8$, or 6.5 ; and $2 \% \mathrm{pO}_{2}$, and under $50 \mathrm{mmHg}$ of hydrostatic pressure, were similarly collected, washed, and fixed. Cells were pelleted and treated with 100 units/mL RNase, and DNA was fluorescently labeled with $0.05 \mathrm{mg} / \mathrm{mL}$ propidium iodide. The proportion of cells in the sub-G0/G1 phase and other cell cycle phases was evaluated with flow cytometry (FACSCaliber; Becton Dickinson, Bedford, MA, USA) and subsequent analysis with FlowJo software (Tree Star Inc., San Carlos, CA, USA).

\section{QUANTITATIVE REAL-TIME POLYMERASE CHAIN REACTION GENE EXPRESSION ASSAY}

The gene expression of cells grown under different levels of extracellular $\mathrm{pH}$, hypoxia, and hydrostatic pressure was determined after $24 \mathrm{~h}$ of exposure to the conditions. This time point was selected based upon previous investigations that identified $24 \mathrm{~h}$ as the time period after which maximal expression of adaptive response genes was observed $(7,8)$. The cDNA obtained from cells grown for $24 \mathrm{~h}$ under normal $\mathrm{pH}$ (7.4) or acidic $\mathrm{pH}$ (6.8); normoxia $\left(20 \% \mathrm{O}_{2}\right)$ or hypoxia $\left(2 \% \mathrm{O}_{2}\right)$; and normal or elevated hydrostatic pressure $(0$ or $50 \mathrm{mmHg})$, was assessed 
via QT-PCR for the relative expression of $C A I X, V E G F-A$, HIF-1A, MMP-9, and TIMP-2 using the TaqMan Gene Expression Assays kit (Applied Biosystems, Foster City, CA, USA) and associated probes (CA IX: assay ID Hs00154208_m1; VEGF-A: assay ID Hs99999070_m1; HIF-1A: assay ID Hs00936368_m1; MMP-9: assay ID Hs00957555_ml; and TIMP-2: assay ID Hs00234278_m1). The manufacturer's protocols were followed for the standardization, validation, and analysis assays, as previously described (18).

Total RNA for reverse transcription was extracted with Trizol (Invitrogen, Carlsbad, CA, USA) and treated with RNase-Free DNase I (QIAGEN, Valencia, CA, USA). cDNA was synthesized using a SuperScript II Wrst-Strand real-time polymerase chain reaction (RT-PCR) kit (Invitrogen). Gene expression was measured by quantitative RT-PCR (qPCR, MX4000, Stratagene, La Jolla, CA, USA) using $50 \mathrm{ng}$ of rat cDNA and $2 \times$ TaqMan Universal PCR Master Mix (Applied Biosystems) with a one-step program $\left(95^{\circ} \mathrm{C}\right.$ for $10 \mathrm{~min}, 95^{\circ} \mathrm{C}$ for $30 \mathrm{~s}$, and $60^{\circ} \mathrm{C}$ for $1 \mathrm{~min}$ for 50 cycles). The hypoxanthine phosphoribosyl-transferase (HPRT) gene was used as an endogenous normalizer. Duplicate samples without cDNA (no template control) for each gene showed no contaminating DNA.

\section{IMMUNOFLUORESCENCE STUDY OF CA IX AND HIF-1 $\alpha$}

Cells were grown in the Nunc Lab-Tek II 4-well Chamber Slide System (Nalge Nunc International, Rochester, NY, USA); each well was seeded with $5 \times 10^{4}$ cells. After culturing the cells at $\mathrm{pH} 7.4$ for $24 \mathrm{~h}$, the medium was replaced with $\mathrm{pH} 7.4,6.8$, or 6.5 media and cells were cultured in either $2 \% \mathrm{O}_{2} / 98 \% \mathrm{~N}_{2}$ or $20 \% \mathrm{O}_{2} / 80 \% \mathrm{~N}_{2}$ for an additional 12, 24, 36, and $48 \mathrm{~h}$. The cells on the glass slides were washed with PBS and fixed with $4 \%$ paraformaldehyde.

An automated immunofluorescence staining protocol was performed with a Discovery XT processor (Ventana Medical Systems, Tucson, AZ, USA). Rabbit polyclonal antibodies were used for the primary incubation. The CA IX antibody (Santa Cruz, CA, USA, Cat. \#sc-25599) was used at a concentration of $2.5 \mu \mathrm{g} / \mathrm{mL}$, and the HIF- $1 \alpha$ antibody (Chemicon, Temecula, CA, USA, Cat. \#AB3883) was used at $12 \mu \mathrm{g} / \mathrm{mL}$. Before the primary antibody incubation, the glass slides were blocked for $30 \mathrm{~min}$ in $10 \%$ normal goat serum, $2 \%$ BSA in PBS. Incubation with the primary antibody was $3 \mathrm{~h}$, followed by $60 \mathrm{~min}$ incubation with biotinylated goat anti-rabbit IgG (Vector Labs, Burlingame, CA, USA, Cat. \#PK6101) diluted 1:200. Normal rabbit IgG $(5 \mu \mathrm{g} / \mathrm{mL})$ was used as an appropriate isotype-negative control. The detection was performed with Streptavidin-HRP D (Ventana Medical Systems), followed by incubation with either Tyramide-Alexa Fluor 488 (Invitrogen, Cat. \#T20922) for CA IX or with Tyramide-Alexa Fluor 568 (Invitrogen, Cat. \#T20914) for HIF-1 $\alpha$.

Cells were visualized using fluorescence microscopy (ZEISS Axioplan2 Imaging). ZEISS AxioVision (ver. 4.6.3.SP1) and Adobe Photoshop (Adobe Systems Inc., San Jose, CA, USA) were used to analyze the quantity of each protein level. Fluorescence photographs were taken with light exposure times of $400 \mathrm{~ms}$ for CA IX and $500 \mathrm{~ms}$ for HIF-1 $\alpha$; two photographs were taken in each group. Fluorescence was quantified with Photoshop, using a previously published method of evaluating luminosity (19). Histograms were derived from the pixel density average from both photographs.

\section{INVASION ASSAY}

An invasion assay was performed on the OS cell lines using the Biocoat Matrigel Invasion Chamber (Becton Dickinson). After culturing the OS cells in pH 7.4 or 6.8 media for $48 \mathrm{~h}(20 \%$ $\mathrm{pO}_{2}, 0 \mathrm{mmHg}$ ), $5 \times 10^{4}$ cells of U2OS, $15 \times 10^{4}$ cells of MG63, or $5 \times 10^{4}$ cells of SaOS2 were added to the invasion chamber and cultured for $24 \mathrm{~h}$ in $\mathrm{pH} 7.4$ media under 2 or $20 \% \mathrm{pO}_{2}$. FCS was used as the chemoattractant; cells incubated without a chemoattractant served as controls. After $24 \mathrm{~h}$, non-invasive cells were removed from the upper surface of the membrane with a cotton swab. The invasive cells on the lower surface of the membrane were fixed with $4 \%$ methanol, stained with toluidine blue, and counted in four separate areas with an inverted microscope (ZEISS, Dublin, CA, USA). An "invasion index" was computed using the manufacturer's analysis protocol, in which the invasion index was defined as the quotient of the percent cell invasion in a test chamber divided by the percent cell invasion in a control chamber.

\section{STATISTICAL ANALYSIS}

Student's $t$ test was used to assess the significance of any differences between the results of each condition relative to control. Each data point shown in the figures is the mean \pm standard error $(n=3$ cassettes/condition), and significance is defined as $P<0.05$.

\section{RESULTS}

\section{CELL PROLIFERATION AND FLOW CYTOMETRY ANALYSIS ON U2OS}

The ratio of TVCC at $72 \mathrm{~h}$ to the TVCC at $0 \mathrm{~h}$ ( $24 \mathrm{~h}$ after seeding) was used to calculate net growth of U2OS cells at various $\mathrm{pH}, \mathrm{pO}_{2}$, and hydrostatic pressure levels after 2 weeks of preconditioning at acidic $\mathrm{pH}$ levels or normal $\mathrm{pH}$ (Figure 1A). The percentage of cells in $S$ phase and in the sub-G0/G1 phase, which correlate with DNA replication activity and apoptosis rate, respectively, are presented in Figures 1B,C. The findings suggest that U2OS tumor growth at $72 \mathrm{~h}$ decreased as $\mathrm{pH}$ decreased (Figure 1A). Previous studies using $\mathrm{pH} 7.4$ media showed that U2OS growth was enhanced under hypoxia and elevated hydrostatic pressure (11); however, our data suggest that hypoxic and hydrostatic pressure levels inhibited growth of U2OS cells grown in acidic media (Figure 1A). In addition, as $\mathrm{pH}$ decreases, the growth of cells exposed to either hypoxic or elevated hydrostatic pressure conditions for a 2-week period was further decreased, while the apoptosis rate after 2 weeks' culture at $\mathrm{pH} 6.5$ was not increased relative to cells cultured at $\mathrm{pH}$ 6.5 for $72 \mathrm{~h}$. Under acidic conditions, the cells' S phase decreased (Figure 1B); the slowing of the cell cycle in U2OS by acidic media was evident during both the 72 -h and the 2 -week growth periods. Apoptosis, however, was not promoted by 2 weeks of exposure to acidic media (Figure 1C; dark bar).

Figure 2A presents the TVCC ratio of all tumor cells after $72 \mathrm{~h}$ under $\mathrm{pH}$ 6.8, with: $20 \% \mathrm{pO}_{2}$, and $0 \mathrm{mmHg}$ hydrostatic pressure; $20 \% \mathrm{pO}_{2}$, and $50 \mathrm{mmHg}$ hydrostatic pressure; $2 \% \mathrm{pO}_{2}$ and $0 \mathrm{mmHg}$ hydrostatic pressure; and $2 \% \mathrm{pO}_{2}$ and $50 \mathrm{mmHg}$ hydrostatic pressure. Comparison with cells grown under $\mathrm{pH} 7.4$ and $20 \% \mathrm{pO}_{2}$ (control condition), suggests that the TVCC ratio of all tumor cell lines is reduced in acidic media. At pH 6.8, the growth of all tumor cells is not promoted by hypoxia or elevated hydrostatic pressure. For all tumor cell lines, no significant difference 


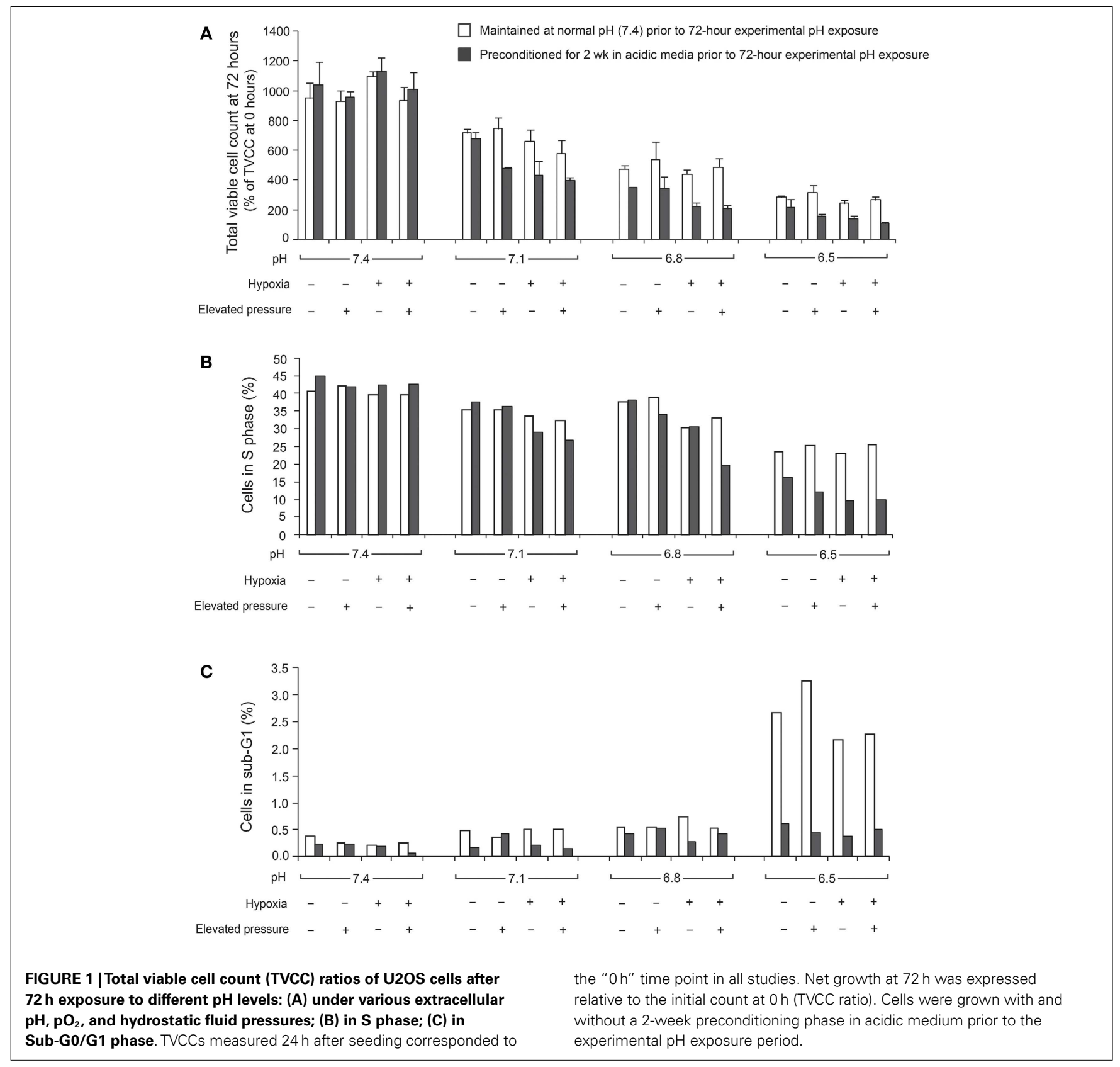

was observed in cell cycle and apoptosis rates of cells preconditioned in acidic media and subsequently grown in acidic media, whether under elevated hydrostatic pressure, hypoxia, or a combination of hypoxia and hydrostatic pressure (data not shown). On the other hand, acidosis was associated with changes in cell cycle (Figure 2B) and apoptosis rates (Figure 2C) compared with $\mathrm{pH}$ 7.4 neutral condition. As seen in Figure 2C, with the exception of the H1299 cell line, apoptosis rates in cells grown under acidic conditions were not strongly affected as extracellular $\mathrm{pH}$ decreased (sub-G0/G1 phase was moderately affected in U2OS cells at $\mathrm{pH}$ 6.5). Further, cell counts performed after trypan-blue staining in both supernatants and detached monolayer cells before and after a 72-h incubation in either $\mathrm{pH} 7.4$ or 6.8 culture medium did not reveal significant cell death. As for apoptosis, OS cell lines were relatively resistant to the influence of acidic media compared with the H1299 lung cancer cell line (Figure 2C).

\section{QUANTITATIVE RT-PCR ASSAY FOR CA IX}

In all cell lines, $C A I X$ mRNA expression was higher under hypoxic conditions than under normoxic conditions (Figure 3), and was related to HIF-1 $\alpha$ expression, as previously reported ( 9 , 20). Furthermore, in OS cell lines, CA IX mRNA was highly expressed under both acidosis and hypoxia. Hydrostatic pressure reduced CA IX gene expression in OS cells; however, in acidic and hypoxic conditions without elevated hydrostatic pressure, $C A$ $I X$ was strongly expressed compared to normoxic and normal 


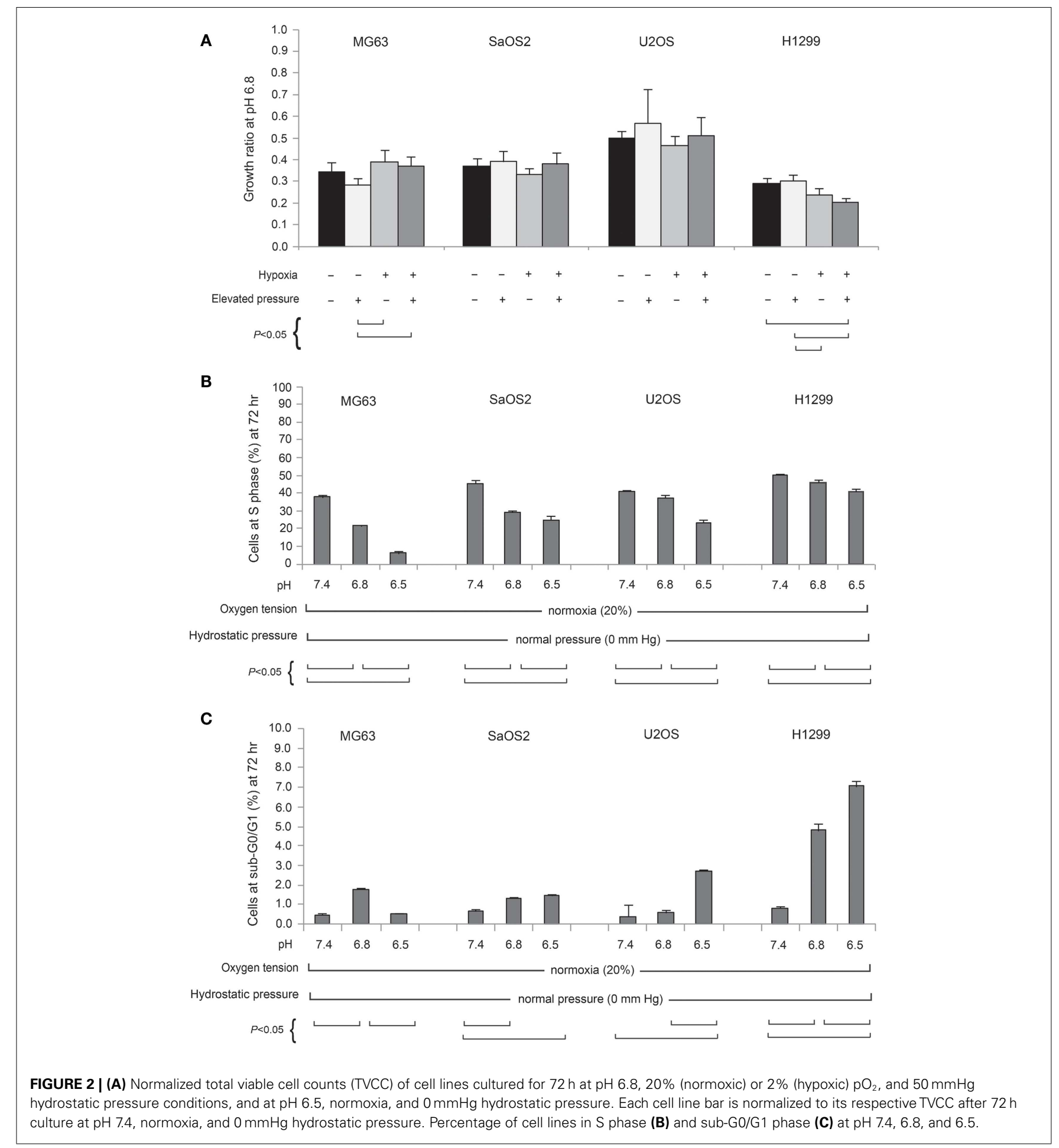

$\mathrm{pH}$ conditions (Figure 3; dark bar). The actual expression of CA IX in OS cells was higher than in H1299 lung cancer cells (Figure 3). Compared with typical cell culture conditions ( $\mathrm{pH}$ 7.4, $20 \%$ oxygen, and $0 \mathrm{mmHg}$ pressure, which we considered to be the "neutral" condition), the combinations of altered microenvironmental conditions increased gene expression by the factors shown in the figure. Specifically, in MG63 cells, hypoxia elevated CA IX expression 4.9-fold over the neutral condition, and acidic $\mathrm{pH}$ elevated expression 8.4-fold, while the combined effect of hypoxia and acidic condition elevated CA IX expression by a factor of 19.3. The combination of hypoxia and acidic $\mathrm{pH}$ elevated $C A I X$ expression 852-fold in U2OS cells and 13.5-fold in SaOS2, while these conditions failed to promote significantly elevated CA IX expression in H1299. 


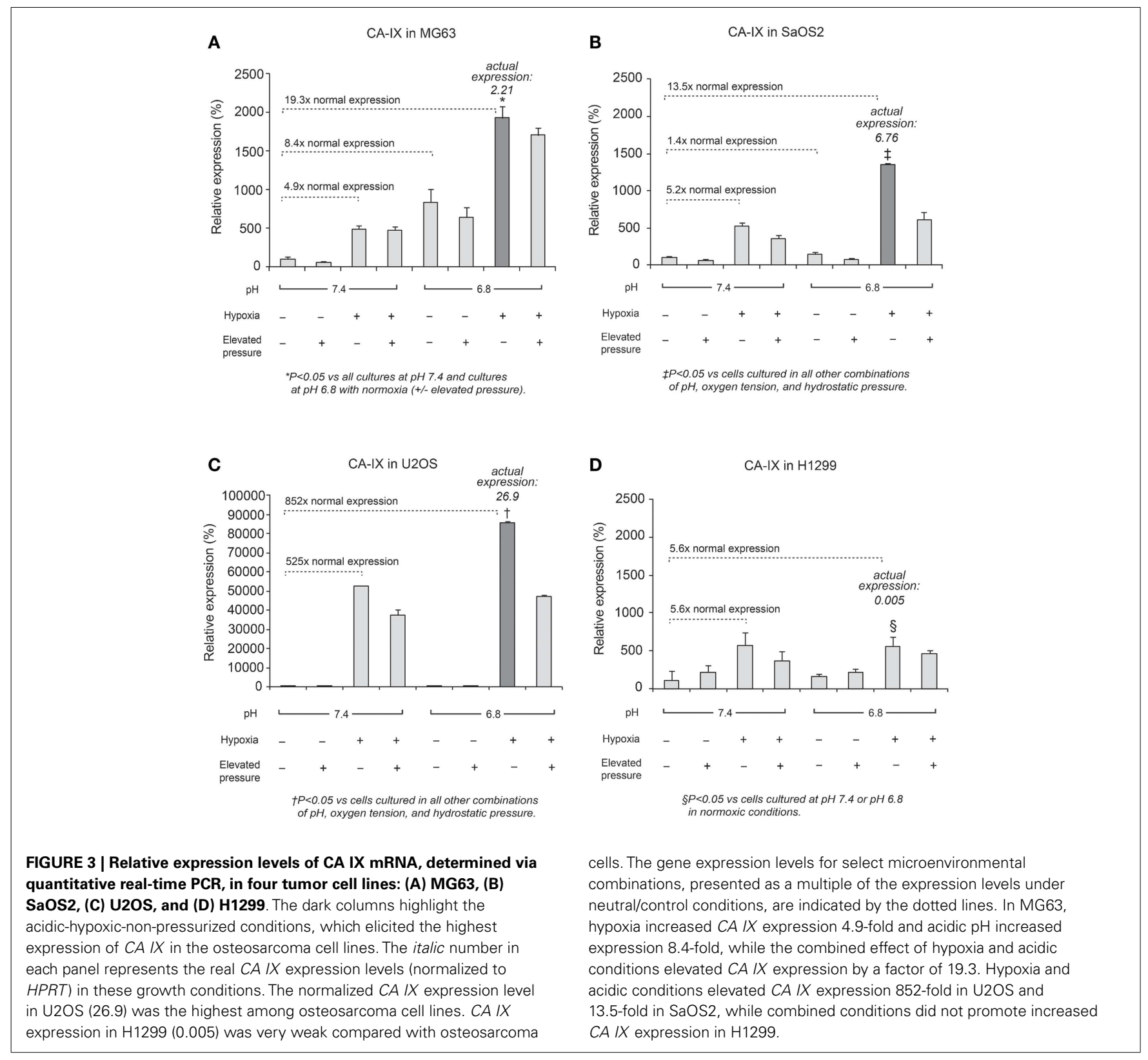

\section{QUANTITATIVE RT-PCR ASSAY FOR VEGF-A}

Expression of VEGF-A mRNA is shown in Figure 4. The combined effect of acidosis, hypoxia, and elevated hydrostatic pressure (dark bar in the display for each cell line) increased VEGF-A mRNA expression significantly compared with control conditions $(P<0.05)$. The combination of acidic $\mathrm{pH}$, hypoxia, and high hydrostatic pressure elicited VEGF-A levels that were 3.3fold higher than the neutral conditions in MG63 cells and 4.1-fold higher than the control conditions in H1299 cells. These findings suggest that VEGF-A expression is additively influenced by combinations of altered microenvironmental factors.

\section{QUANTITATIVE RT-PCR ASSAY FOR HIF-1A}

Generally, HIF- $1 \alpha$ is rapidly degraded by proteasomal degradation. During low oxygen tension conditions $\left(2 \% \mathrm{pO}_{2}\right)$, this degradation is inhibited, leading to increased HIF-1A (21). In contrast, our findings demonstrated that $H I F-1 A$ was increased by hypoxic conditions in SaOS2 and U2OS cell lines as previously reported (Figure 5). With respect to HIF-1A mRNA levels, elevated IFP did not affect the expression of HIF-1A (elevated IFP conditions are not included in Figure 5). Furthermore, low $\mathrm{pH}$ led to increased HIF-1A without stimulation by hypoxia in SaOS2 and U2OS. The combinatorial effect of hypoxia and acidity did not promote further HIF-1A expression in MG63 and H1299, while these microenvironmental parameters additively promoted mRNA of the hypoxia-induced factors CA IX and VEGF-A.

\section{MMP-9 AND TIMP-2 EXPRESSION}

In Figures 6 and 7, mRNA expression levels of MMP-9 and TIMP-2 are presented. The level of MMP-9/HPRT (the endogenous control 


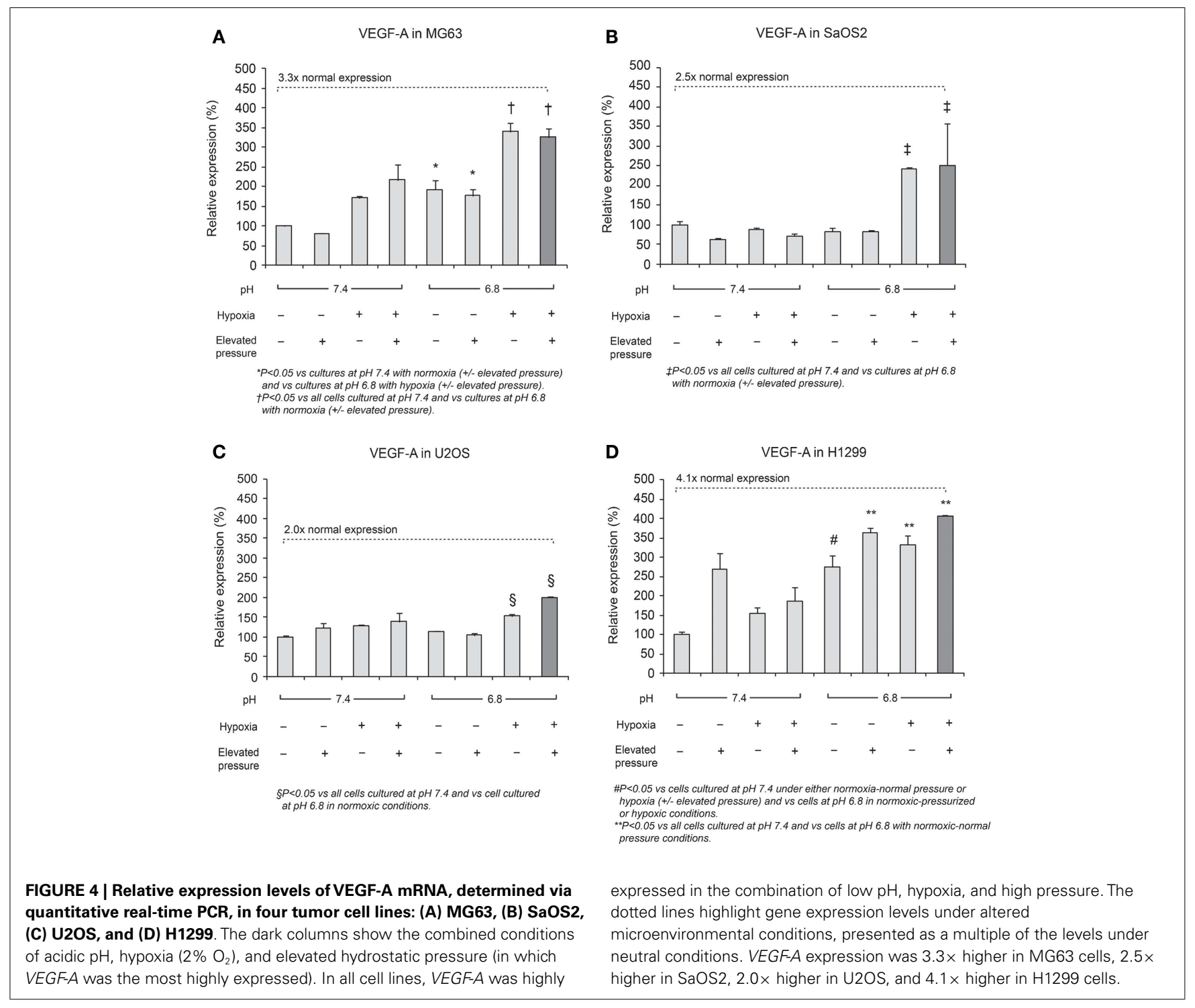

for mRNA expression) was 5.57 in MG63 cells, 0.36 in SaOS2, 71.9 in U2OS, and 2.74 in H1299 cells. MMP-9 was more highly expressed in MG63 and U2OS cells than in SaOS2 and H1299 cells. In MG63 and SaOS2, MMP-9 expression was higher in acidic conditions than in control conditions (Figure 6). In MG63 cells, TIMP-2 was more highly expressed in acidic media than in normal $\mathrm{pH}$ media (Figure 7; $P<0.05$ ), but in the other cell lines, acidic growth conditions didn't increase the expression of TIMP-2. Elevated hydrostatic pressure promoted greater expression of $M M P-9$ in SaOS2 and H1299 cells. For MMP-9 and TIMP-2, acidic media was the most influential factor for two (MG63 and SaOS2) of three OS cell lines. Elevated hydrostatic pressure and acidic media each enhanced mRNA expression of MMP-9 in tumor cells.

\section{IMMUNOFLUORESCENCE STUDIES: CA IX AND HIF-1 $\alpha$}

$C A I X$ and HIF-1A mRNA expression was affected more by acidic $\mathrm{pH}$ and hypoxia than by elevated IFP. The effects of $\mathrm{pH}$ and hypoxia on CA IX and HIF-1 $\alpha$ protein level expression and

their relationship to tumor invasiveness were also studied using immunofluorescence with in vitro cell culture. The immunofluorescence images of colocalized CA IX and HIF- $1 \alpha$ in U2OS are presented in Figure 8. The immunofluorescence brightness indices corresponding to CA IX and HIF-1 $\alpha$ expression in each cell line are graphically represented in Figures 9 and 10. U2OS cells expressed CA IX consistently under normal $\mathrm{pH}$ and normoxic conditions, but exposure to acidic media and hypoxic conditions resulted in additive upregulation of CA IX in U2OS and SaOS2 cells (Figures 7 and 8). These data were corroborated by the upregulation of CA IX mRNA expression in the quantitative RT-PCR analysis (Figure 3). On examining the correlation between HIF-1A mRNA expression and HIF- $1 \alpha$, the combinatorial effect of low $\mathrm{pH}$ and hypoxia promoted HIF-1 $\alpha$ expression in U2OS and $\mathrm{SaOS} 2$, while the exposure to these microenvironmental conditions did not upregulate expression of HIF-1A mRNA. The expression of HIF-1A mRNA and HIF- $1 \alpha$ were not parallel under the combined acidotic and hypoxic condition. The minimal differences in CA 

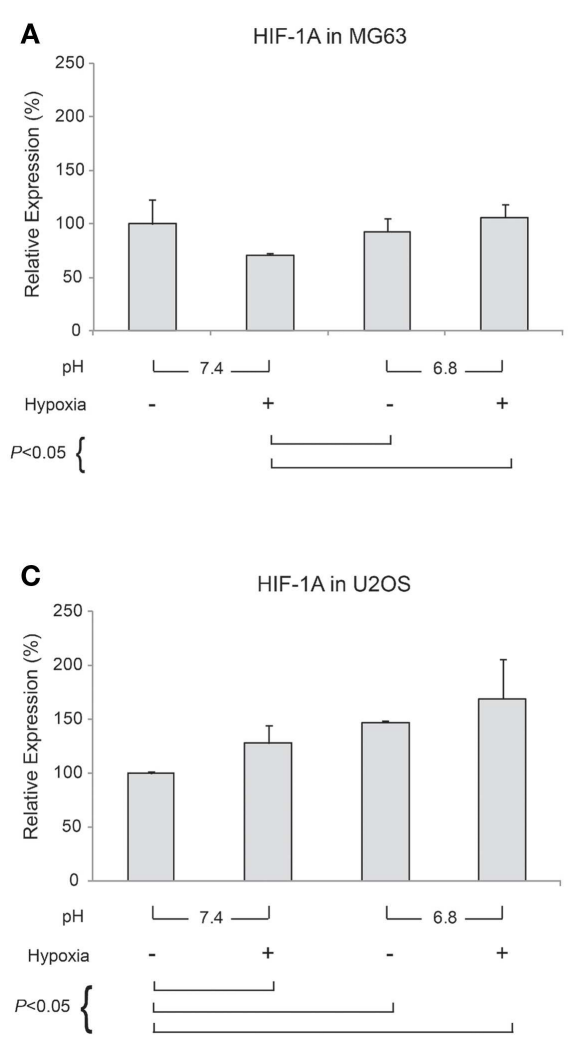

FIGURE 5 | Relative expression levels of HIF-1A mRNA, determined via quantitative real-time PCR, in four tumor cell lines: (A) MG63, (B) SaOS2, (C) U2OS, and (D) H1299. All graphs show mRNA expression under normal
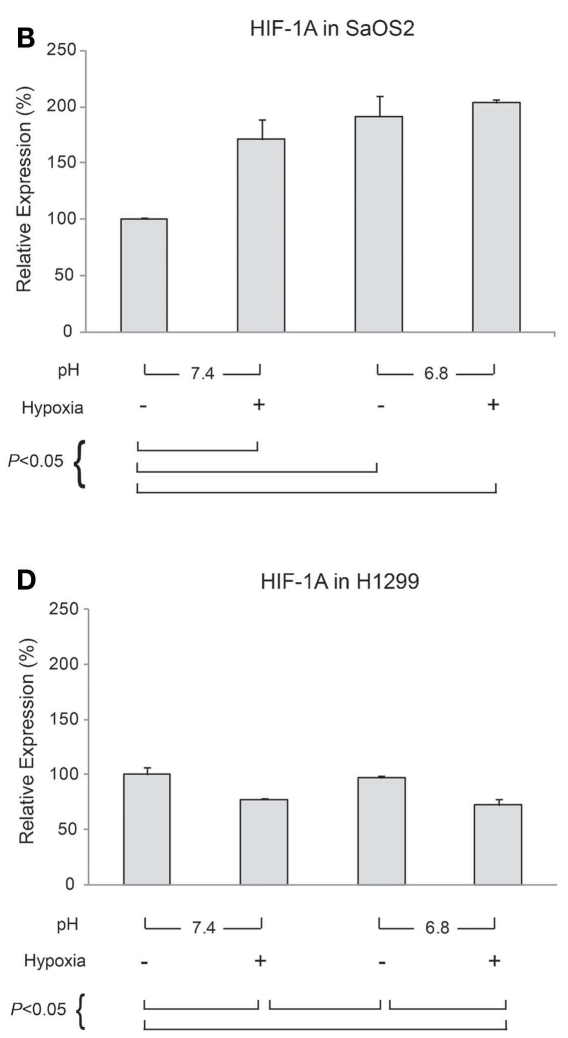

hydrostatic pressure, and indicate statistically significant differences between different combinations of $\mathrm{pH}(7.4$ or 6.8$)$ and either normoxia $\left(20 \% \mathrm{O}_{2}\right)$ or hypoxia $\left(2 \% \mathrm{O}_{2}\right)$
IX immunofluorescence staining between MG63 and H1299 cells in various growth conditions (Figures 9C,D) were also consistent with the level of mRNA expression data from quantitative RT-PCR (Figure 3). The expression of CA IX and HIF-1 $\alpha$ were generally parallel in all cell lines (Figures 9 and 10).

\section{INVASION ASSAY}

The invasion indices for MG63, SaOS2, and U2OS cells are shown in Table 1. The invasion index of U2OS cells was higher in acidic conditions, with or without hypoxia, than in the normal $\mathrm{pH}-$ hypoxic and normal $\mathrm{pH}$-normoxic conditions $(P<0.05)$. The invasion index of SaOS2 cells was not upregulated by either acidic or hypoxic conditions.

\section{DISCUSSION}

In vitro tumor cell culture conditions typically lack the elevated pressure, hypoxia, and acidosis frequently observed in solid tumors in vivo $(11,12)$. Heretofore, experimental reports have examined these physical-chemical factors in isolation, not in concert. To evaluate the combinatorial effects of microenvironmental factors on the growth of U2OS, SaOS2, MG63, and H1299 cell lines, we used our novel cell culture system to individually control these parameters and to independently simulate various combinations of elevated pressure, hypoxia, and acidity that occur in vivo. We demonstrated that these factors exert independent and additive effects on both cellular growth and the expression of genes that regulate malignant phenotype. These findings suggest a need to control for each of these physical-chemical environmental conditions in future cell culture and chemosensitivity studies in the development of future therapies for OS.

In U2OS cells, continuous exposure to acidic conditions reduced proliferation and promoted invasiveness but did not significantly influence apoptosis. Cells cultured in acidic media for $72 \mathrm{~h}$ under hypoxic or elevated hydrostatic pressure did not evince tumor cell proliferation as was observed in cells cultured under normal $\mathrm{pH}$ (2). However, continuous exposure to acidic conditions for 2 weeks under hypoxic or elevated hydrostatic pressure mediated cell cycle progression and downregulated cell growth. We also observed that U2OS cell cycling slowed with decreasing extracellular $\mathrm{pH}$ ( $\mathrm{pH} 7.1-6.8$ ), while $\mathrm{pH}$ below 6.8 induced apoptosis (Figures 1B,C). This observation might be consistent with in vivo observations of the center of human OS tumors, which tend to be necrotic and acidic (1). Our data demonstrate the complex interactions of microenvironmental factors on tumor physiology and indicate that $\mathrm{pH}$ has the most profound influence on cell progression.

In our cell proliferation studies, neither hypoxia nor elevated hydrostatic pressure promoted proliferation in acidic media. Our studies demonstrated that mildly acidic $\mathrm{pH}$ downregulated tumor growth, even under conditions of hypoxia or elevated pressure. In 


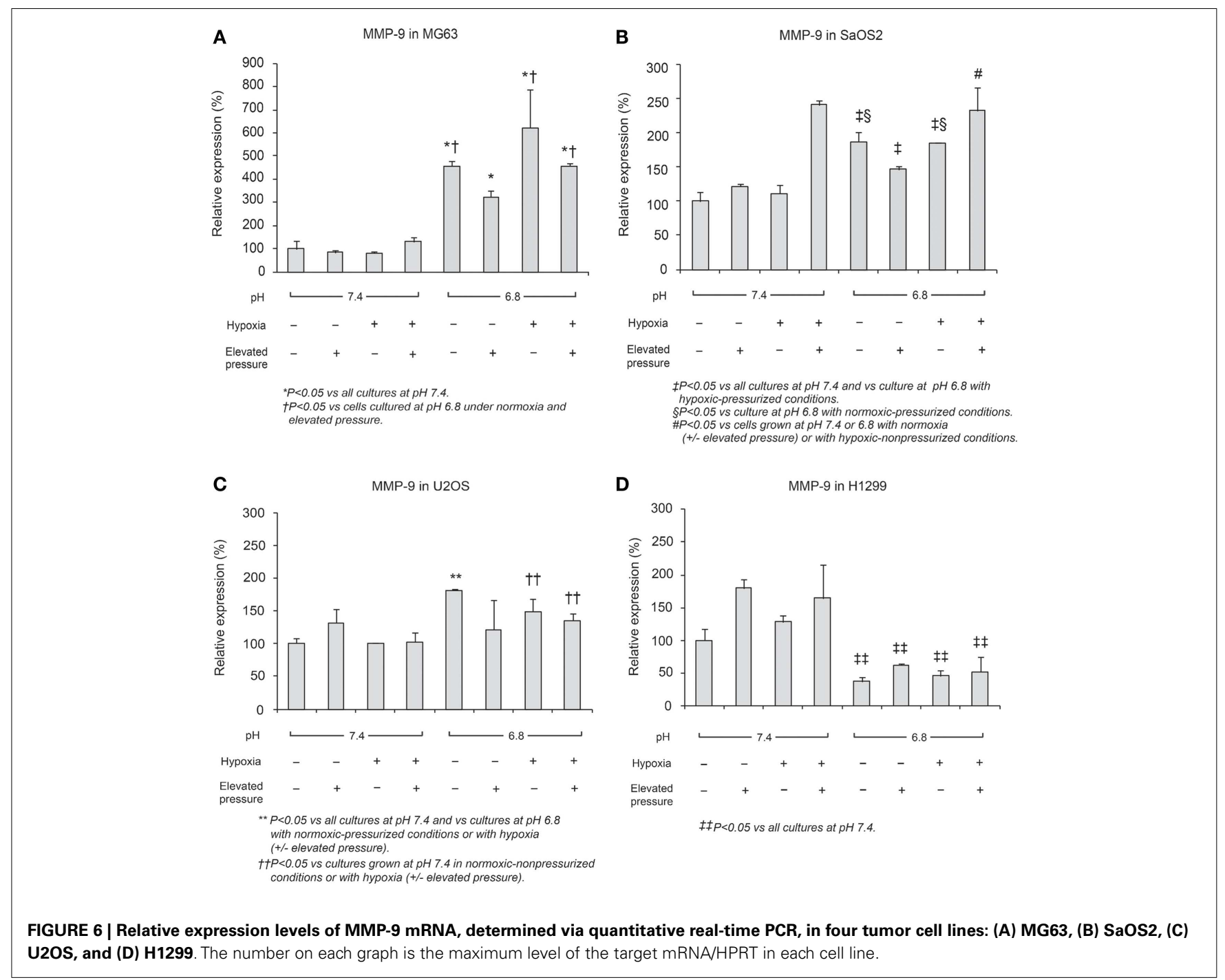

our OS cell lines, although more acidic conditions were not associated with cellular proliferation, they also were not associated with necrosis or apoptosis. Hence, we can hypothesize from the proliferation study that the survival of OS cells in acidic conditions may be achieved through reduced rates of cellular metabolism, adaptation to acidity, or migration to regions with normal $\mathrm{pH}, \mathrm{pO}_{2}$, and IFP.

On the other hand, VEGF-A mRNA was expressed in acidic, hypoxic, and elevated pressure conditions. A previous study by our group demonstrated that VEGF- $A$ in cells cultured at normal $\mathrm{pH}$ was not upregulated by elevated hydrostatic pressure (13). However, we speculate that the combination of hypoxia with low $\mathrm{pH}$ and elevated IFP, conditions that occur within a tumor's central region or in regions away from blood vessels in vivo, may induce angiogenesis through increased expression of VEGF.

Studies have reported CA IX expression in several carcinomas, such as renal cell (22), colorectal (23), non-small cell lung $(24,25)$, cervical (26), bladder (27), nasopharyngeal carcinoma (28), breast (29), and soft tissue sarcoma (30), but it is absent from most normal tissues. CA IX has long been examined as a marker of tumor hypoxia, and is quickly and extensively upregulated under hypoxic conditions $(31,32)$. Furthermore, a few published reports have demonstrated that extracellular acidosis elevates CA IX expression in tumor cells $(7,8)$. CA IX mediates the transport of an intracellular $\mathrm{H}^{+}$to the extracellular space to maintain homeostasis in tumor cells (11). Thus, we hypothesized that CA IX is not only a biomarker for hypoxia, but also serves as a marker of acidosis in tumors.

In our study, CA IX mRNA was highly expressed under hypoxia in all OS tumor cell lines, and the combination of acidosis and hypoxia further promoted CA IX mRNA expression. Hydrostatic pressure downregulated the effect of hypoxia in all OS cell and lung cancer cell lines, and acidosis induced upregulation of $C A I X$ in all OS cell lines. But CA IX was more highly expressed in cells cultured in acidic-hypoxic-non-pressurized media conditions than in OS cells cultured under normal $\mathrm{pH}$ and normal oxygen media (Figure 3). This CA IX mRNA finding was confirmed by immunofluorescence study (Figure 8). CA IX expression was highest in the combination of acidic ( $\mathrm{pH} 6.8$ ) and hypoxic growth conditions for the U2OS and SaOS2 OS cell lines (Figures 8 and 9), as indicated 

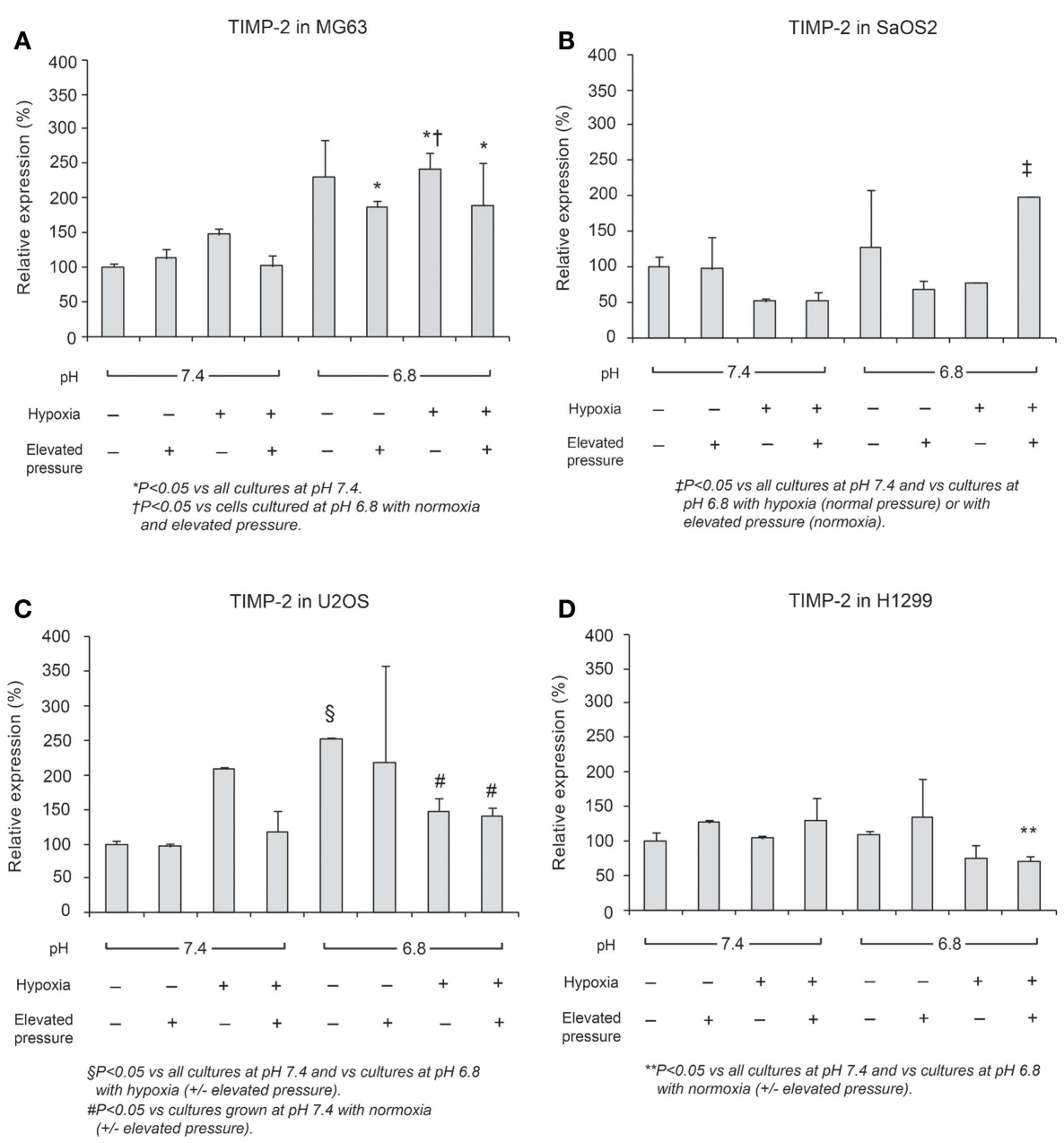

FIGURE 7 | Relative expression levels of TIMP-2 mRNA, determined via quantitative real-time PCR, in four tumor cell lines: (A) MG63, (B) SaOS2, (C) U2OS, and (D) H1299.

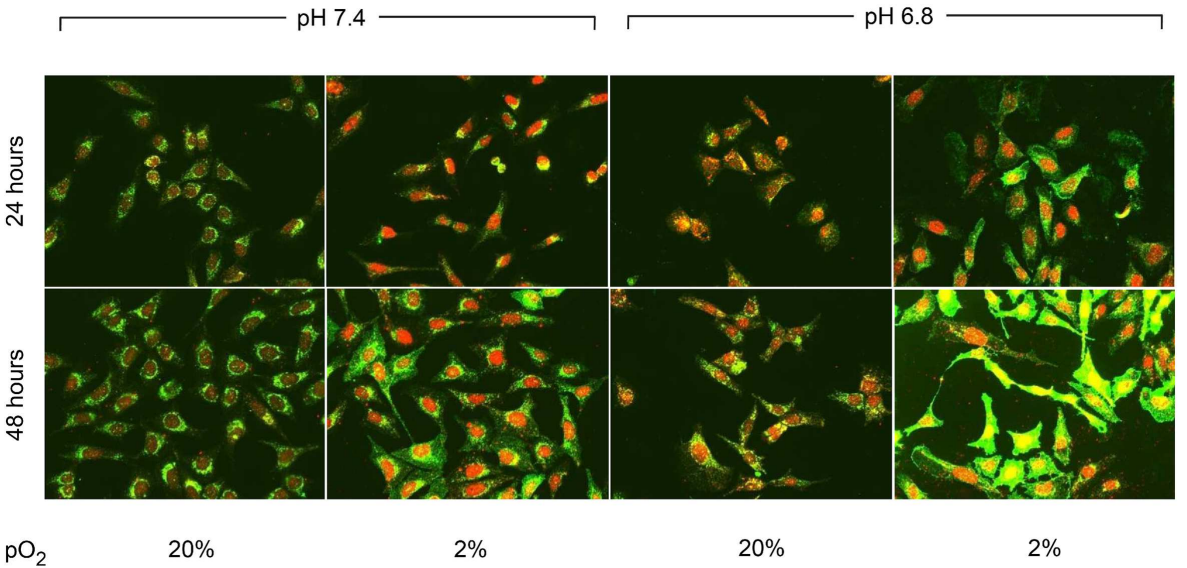

FIGURE 8 | Immunofluorescent staining demonstrated the changes in CA IX (green) and HIF-1 $\alpha$ (red) expression at 24 and $48 \mathrm{~h}$ of incubation in varying microenvironmental conditions. CA IX expression was highly promoted by the combination of acidic $\mathrm{pH}$ and hypoxia. 

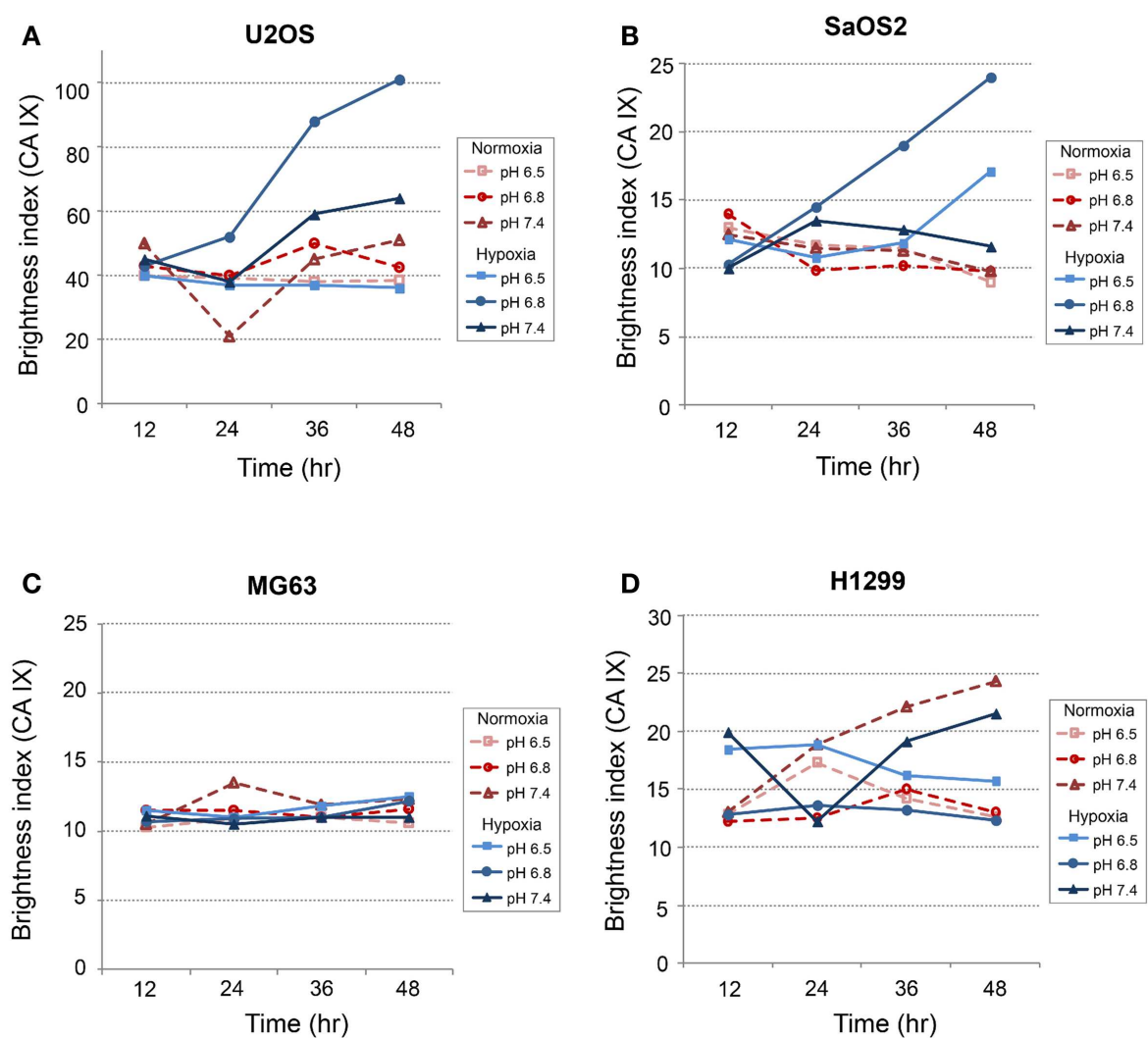

FIGURE 9 | Expression level of CA IX in (A) SaOS2, (B) U2OS, (C) MG63, and (D) H1299 cells

by the mRNA study (Figure 3). CA IX in these OS cell lines was regulated by the combination of hypoxia and acidity. Our study demonstrated that CA IX, long regarded as a hypoxia-induced factor, was upregulated by the complex conditions of hypoxia and acidity, although these combined conditions did not promote increased expression of HIF-1A mRNA (Figure 5). It has been reported that extracellular acidosis elevates CA IX expression in tumor cells, even in normoxic conditions $(7,8,49)$. This is further supported by studies of the von Hippel-Lindau tumor suppressor protein (pVHL), the main negative regulator of HIF-1, which can downregulate CA IX (obviously as a direct HIF-1 target) (33, 34). HIF is degraded in conditions of normal oxygen tension by pVHL, but is stabilized by hypoxia. CA IX, as part of the hypoxic acidification mechanism, might facilitate the nucleolar sequestration of pVHL and activation of HIF, which has been described as a $\mathrm{pH}$-dependent mechanism that may serve a protective role in reoxygenated cells (35). In this case, HIF-mediates increases in the level and activity of CA IX, resulting in enhanced acidification, and might create a feedback loop that leads to prolonged HIF activation. As a result of this prolonged HIF activation, CA IX would be increased in hypoxic-acidic conditions without upregulation of HIF-1A mRNA. CA IX is reported to have a major role in regulating $\mathrm{H}^{+}$flux, while blockade of CA IX results in increased cell death (9). The immunofluorescence study demonstrates that this is one mechanism for acidic adaptation and suggests that CA IX may be a potential target for therapy and a marker for OS (51).
Physical-chemical conditions affect markers of aggressive behavior. In acidic-hypoxic-hydrostatically pressurized media conditions, the TVCC at $72 \mathrm{~h}$ was reduced. However, our studies demonstrated that the mRNA of MMP-9, a marker of invasive potential, was upregulated in acidic-hypoxic-hydrostatically pressurized media conditions for U2OS and MG63 cells (Figure 6). Based on the HPRT-normalized levels of MMP-9, we demonstrated that this metalloprotease was more highly expressed in MG63 and U2OS cells than in SaOS2 and H1299 cells. Increased levels of MMP-9 under acidic-hypoxic conditions may have contributed to the increased invasive activity observed in the MG63 and U2OS cell lines (Table 1), and this metastatic potential may be further influenced by acidosis- and hypoxia-associated changes in interstitial pressure $(36,37)$. Although invasive potential under hydrostatic pressure was not specifically examined in this study, our findings do suggest that elevated pressure promotes VEGF-associated angiogenesis.

The high metabolic and growth rates of tumor cells deplete local supplies of oxygen and nutrients, promoting a switch from aerobic to anaerobic metabolism. This contributes to extracellular acidosis and slows down the cell cycle, as our proliferation study revealed. With further growth, the tumor's IFP increases; eventually local hypoxia, acidic $\mathrm{pH}$, and high hydrostatic pressure conditions become severe in the tumor center or areas distant from the tumor vasculature. The combination of these factors exert multiple biological effects, inducing CA IX 

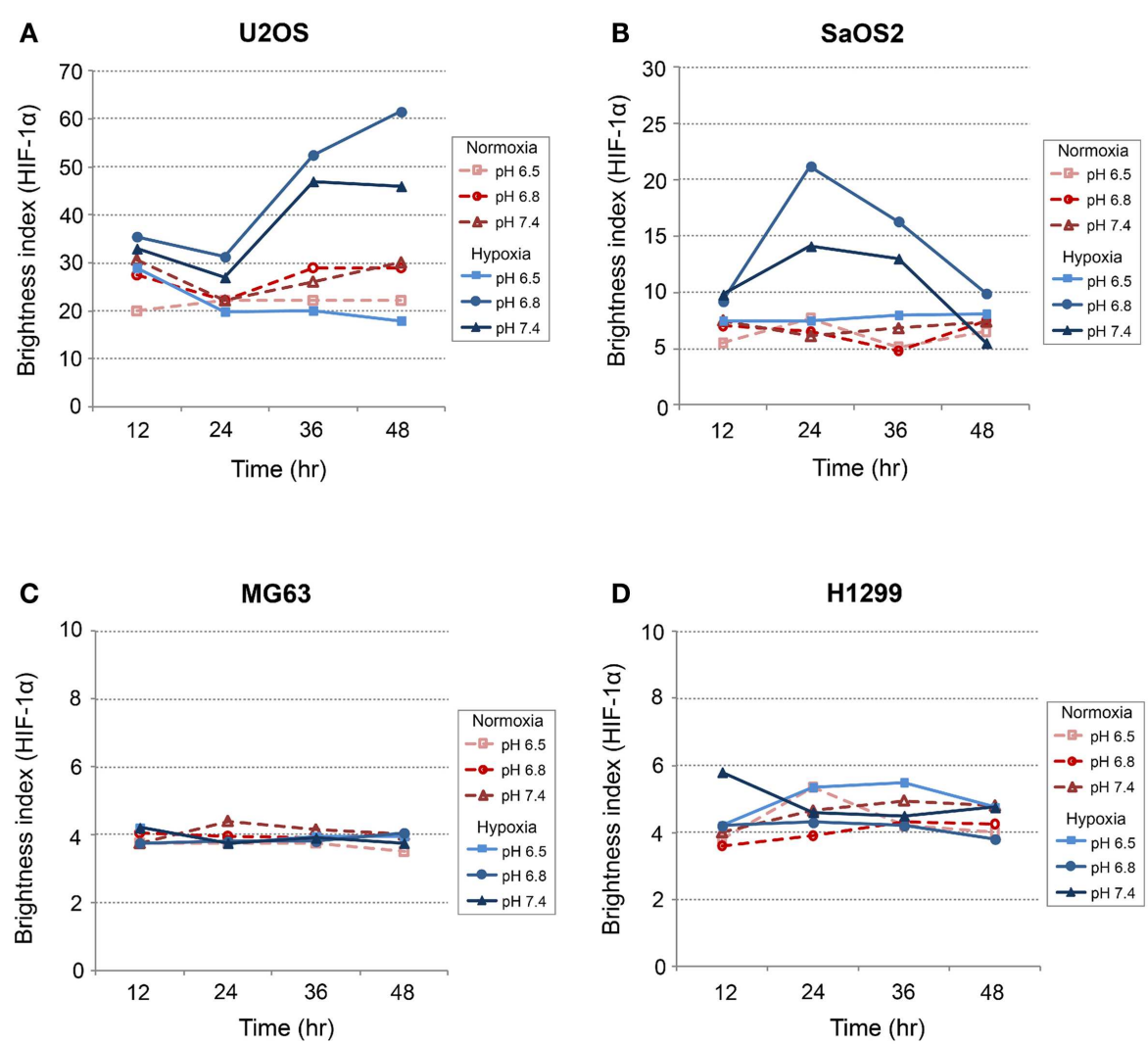

FIGURE 10 | Expression level of HIF-1 $\alpha$ in (A) SaOS2, (B) U2OS, (C) MG63, and (D) H1299 cells.

Table 1 |The invasion index of three osteosarcoma cell lines.

\begin{tabular}{lcccc}
\hline Cell line & \multicolumn{4}{c}{ Media conditions } \\
\cline { 2 - 5 } & $\mathbf{p H ~ 7 . 4 ,}$ & $\mathbf{p H ~ 6 . 8 ,}$ & $\mathbf{p H ~ 7 . 4 ,}$ & $\mathbf{p H ~ 6 . 8 ,}$ \\
& $\mathbf{2 0 \% \mathbf { ~ O } _ { \mathbf { 2 } }}$ & $\mathbf{2 0 \%} \mathbf{~ O}_{\mathbf{2}}$ & $\mathbf{2 \%} \mathbf{~ O}_{\mathbf{2}}$ & $\mathbf{2 \%} \mathbf{~ O}_{\mathbf{2}}$ \\
\hline MG63 & $7.38 \pm 1.3$ & $8.26 \pm 1.3$ & $7.69 \pm 4.0$ & $16.65 \pm 1.7^{*}$ \\
SaOS2 & $14.20 \pm 5.0$ & $9.28 \pm 3.7$ & $17.60 \pm 5.8$ & $9.04 \pm 4.2$ \\
U2OS & $9.69 \pm 5.8$ & $31.72 \pm 4.2^{\dagger}$ & $16.53 \pm 5.9$ & $32.03 \pm 6.6^{\dagger}$
\end{tabular}

*For MG63: $P<0.05$ for acidic-hypoxic conditions vs. normal $\mathrm{pH}$ and acidicnormoxic conditions.

${ }^{\dagger}$ For U2OS: $\mathrm{P}<0.05$ for acidic-hypoxic and acidic-normoxic conditions vs. $\mathrm{pH} 7.4$ (with and without hypoxia).

to adapt to significantly acidic conditions; upregulating angiogenesis via VEGF to improve hypoxia and/or low nutrition; and increasing expression of MMP-9 to enhance tumor cell invasion and migration to new microenvironments conducive to further growth.

Overall, U2OS most consistently responded to microenvironmental changes with increased invasive potential and altered expression of biomarkers. The higher invasive potential of U2OS relative to the other OS cell lines in our study is consistent with prior reports $(15,38)$; MMP-9, one marker of invasiveness, is consistently expressed in U2OS as well as human OS biopsy tissue
(38). With respect to expression of both MMP-9 and TIMP2, MG63 exhibited the most pronounced upregulation response to an in vitro microenvironment that most resembled in vivo tumor growth conditions; both of these biomarkers are consistently expressed in OS biopsy samples (38). Across the individual OS cell lines in our studies, some level of variation in the phenotypic responses to microenvironment alteration was evident and may be attributable to patient-specific genotypic variation and differences in metastatic potential among the tumors from which the cell lines were derived (50). Reapplication of microenvironmental parameters that typify OS tumors (hypoxia, high IFP, acidosis), achieved through our novel cell culture apparatus, can facilitate the restoration of previous in vivo phenotypic characteristics, including differences in tumor cells innate genotypic ability to respond to evolving microenvironmental conditions in vivo.

Since cell-capillary diffusion distances are greater in tumors, diffusive coupling is poor and can compound extracellular acidosis $(11,48)$. It is widely understood that CA IX and VEGF expression levels are influenced by levels of HIF-1, which promotes tumor invasiveness. In our study, genes and proteins associated with angiogenesis and invasive potential were also influenced by the additive effects of increased acidosis, hypoxia, and IFP. The tumor cells exposed to severe acidosis exhibited a tendency toward apoptosis or cell cycle arrest, an effect that was compounded by hypoxia and/or elevated hydrostatic pressure. 
Tumor cells that migrate to an anatomic location with neutral $\mathrm{pH}$, such as a lung, respond to the elevated hydrostatic pressure with enhanced growth. A tumor's microenvironment may synergistically induce metabolic and phenotypic alterations that control the tumor's survival by regulating cell proliferation, angiogenesis, and invasiveness.

A number of factors limit the extrapolation of our results to in vivo tumor growth and invasiveness. First, tumor cells in vitro receive complete nutrition from cell culture media, in contrast to the compromised delivery of nutrients by the altered vasculature within a tumor in vivo, particularly within the most central regions. Second, because the OptiCell chamber membrane is not compatible with immunofluorescence staining techniques, the effects of elevated pressure could not be evaluated via immunofluorescence studies. Additionally, our culture system allowed application of only a single hydrostatic pressure and could not replicate the in vivo decreasing pressure gradient that extends from a tumor's central region to peripheral regions (39). This gradient may be responsible for the differential, location-dependent expression of angiogenic and hypoxic biomarkers that has recently been reported (40). Third, we did not employ any three-dimensional culture systems to examine the effects of microenvironmental factors on spheroidal tumor cell aggregates, which recapitulate in vivo tumor growth

\section{REFERENCES}

1. Matsubara T, Kusuzaki K, Matsumine A, Shintani K, Satonaka H, Uchida A. Acridine orange used for photodynamic therapy accumulates in malignant musculoskeletal tumors depending on $\mathrm{pH}$ gradient. Anticancer Res (2006) 26:187-93.

2. Nathan SS, Diresta GR, CasasGanem JE, Hoang BH, Sowers R, Yang R, et al. Elevated physiologic tumor pressure promotes proliferation and chemosensitivity in human osteosarcoma. Clin Cancer Res (2005) 11:2389-97. doi:10. 1158/1078-0432.CCR-04-2048

3. Fukumura D, Jain RK. Tumor microenvironment abnormalities: causes, consequences, and strategies to normalize. J Cell Biochem (2007) 101:937-49. doi:10.1002/jcb.21187

4. Gatenby RA, Gillies RJ. Why do cancers have high aerobic glycolysis? Nat Rev Cancer (2004) 4:891-9. doi:10.1038/nrc1478

5. Gillies RJ, Raghunand N, Karczmar GS, Bhujwalla ZM. MRI of the tumor microenvironment. J Magn Reson Imaging (2002) 16:430-50. doi:10.1002/jmri.10181

6. El Naggar A, Clarkson P, Zhang F, Mathers J, Tognon C, Sorensen PH. Expression and stability of hypoxia inducible factor lalpha in osteosarcoma. Pediatr Blood Cancer (2012) 59:1215-22. doi:10.1002/pbc.24191

7. Sorensen BS, Alsner J, Overgaard J, Horsman MR. Hypoxia induced expression of endogenous markers

more closely; such three-dimensional cellular growth influences cell metabolism and, combined with hypoxia, can increase invasive potential in MG63 cells $(41,42)$. Finally, as with any in vitro system for the study of malignant tumors, the lack of an extracellular matrix (ECM) precludes the examination of any factors which could contribute further additive effects to tumor cell growth and metastatic potential; in the case of OS, the influences of MMP/TIMP interactions and ECM-associated growth factors on invasive potential have been examined but have not yet been fully elucidated $(14,15,43-47)$. However, despite these limitations, this study suggests that tumor microenvironmental factors must be considered in aggregate and that the control of tumor microenvironmental factors, and/or expression of CA IX and VEGF, should be among the important targets for examination in the development of future therapies for malignant tumors.

\section{ACKNOWLEDGMENTS}

We thank the Japan Society for the Promotion of Science, and the Maynard Research Fund that each provided partial funding of this research. This work was performed at the Orthopaedic Research Laboratory, Memorial Sloan-Kettering Cancer Center, New York, NY, USA. We also thank Rosalind Simmons for editorial assistance.

factors in osteosarcoma. J Orthop Res (2008) 26:1520-5. doi:10.1002/ jor.20633

14. Ferrari C, Benassi S, Ponticelli F, Gamberi G, Ragazzini P, Pazzaglia L, et al. Role of MMP-9 and its tissue inhibitor TIMP-1 in human osteosarcoma: findings in 42 patients followed for 1-16 years. Acta Orthop Scand (2004) 75:487-91. doi:10.1080/00016470410001295-1

15. Fromigue O, Hamidouche Z, Marie PJ. Blockade of the RhoA-JNK-cJun-MMP2 cascade by atorvastatin reduces osteosarcoma cell invasion. J Biol Chem (2008) 283:30549-56. doi:10.1074/jbc.M801436200

16. Healey JH, DiResta GR. Measurement of interstitial fluid pressure and blood flow in human bone tumors and adjacent normal tissue. Transactions of the 44th Annual Meeting of the Orthopaedic Research Society. New Orleans, LA: Orthopaedic Research Society (1998). 980 p.

17. Zachos TA, Aiken SW, Diresta GR, Healey JH. Interstitial fluid pressure and blood flow in canine osteosarcoma and other tumors. Clin Orthop Relat Res (2001) 385:230-6. doi:10.1097/00003086-20010400000034

18. Banerjee D, Gorlick R, Liefshitz A, Danenberg K, Danenberg PC, Danenberg PV, et al. Levels of E2F-1 expression are higher in lung metastasis of colon cancer as compared with hepatic metastasis and correlate with levels of thymidylate synthase. Cancer Res (2000) 60:2365-7.

19. Kirkeby S, Thomsen CE. Quantitative immunohistochemistry of fluorescence labelled probes using lowcost software. I Immunol Methods (2005) 301:102-13. doi:10.1016/j. jim.2005.04.006

20. Kaluz S, Kaluzova M, Liao SY, Lerman M, Stanbridge EJ. Transcriptional control of the tumorand hypoxia-marker carbonic anhydrase 9: a one transcription factor (HIF-1) show? Biochim Biophys Acta (2009) 1795:162-72. doi:10.1016/j. bbcan.2009.01.001

21. Richard DE, Berra E, Pouyssegur J. Angiogenesis: how a tumor adapts to hypoxia. Biochem Biophys Res Commun (1999) 266:718-22. doi: 10.1006/bbrc.1999.1889

22. Liao SY, Aurelio ON, Jan K, Zavada J, Stanbridge EJ. Identification of the MN/CA9 protein as a reliable diagnostic biomarker of clear cell carcinoma of the kidney. Cancer Res (1997) 57:2827-31.

23. Saarnio J, Parkkila S, Parkkila AK, Haukipuro K, Pastorekova S, Pastorek J, et al. Immunohistochemical study of colorectal tumors for expression of a novel transmembrane carbonic anhydrase, MN/CA IX, with potential value as a marker of cell proliferation. Am J Pathol (1998) 153:279-85. doi:10.1016/ S0002-9440(10)65569- 1 
24. Giatromanolaki A, Koukourakis MI, Sivridis E, Pastorek J, Wykoff $\mathrm{CC}$, Gatter $\mathrm{KC}$, et al. Expression of hypoxia-inducible carbonic anhydrase- 9 relates to angiogenic pathways and independently to poor outcome in non-small cell lung cancer. Cancer Res (2001) 61:7992-8.

25. Vermylen P, Roufosse C, Burny A, Verhest A, Bosschaerts T, Pastorekova S, et al. Carbonic anhydrase IX antigen differentiates between preneoplastic malignant lesions in non-small cell lung carcinoma. Eur Respir J (1999) 14:80611. doi:10.1034/j.1399-3003.1999. 14d14.x

26. Olive PL, Aquino-Parsons C, MacPhail SH, Liao SY, Raleigh JA, Lerman MI, et al. Carbonic anhydrase 9 as an endogenous marker for hypoxic cells in cervical cancer. Cancer Res (2001) 61: 8924-9.

27. Turner KJ, Crew JP, Wykoff CC, Watson PH, Poulsom R, Pastorek J, et al. The hypoxia-inducible genes VEGF and CA9 are differentially regulated in superficial vs. invasive bladder cancer. $\mathrm{Br} \mathrm{J}$ Cancer (2002) 86:1276-82. doi:10.1038/sj. bjc. 6600215

28. Hui EP, Chan AT, Pezzella F, Turley H, To KF, Poon TC, et al. Coexpression of hypoxia-inducible factors lalpha and 2alpha, carbonic anhydrase IX, and vascular endothelial growth factor in nasopharyngeal carcinoma and relationship to survival. Clin Cancer Res (2002) 8:2595-604.

29. Span PN, Bussink J, Manders P, Beex LV, Sweep CG. Carbonic anhydrase9 expression levels and prognosis in human breast cancer: association with treatment outcome. $\mathrm{Br} J \mathrm{Can}$ cer (2003) 89:271-6. doi:10.1038/sj. bjc. 6601122

30. Maseide K, Pintilie M, Kandel R, Hill RP. Can sparsely and heterogeneously expressed proteins be detected using tissue microarrays? A simulation study of the hypoxia marker carbonic anhydrase IX (CA IX) in human soft tissue sarcoma. Pathol Res Pract (2008) 204:175-83. doi:10.1016/j.prp.2007.10.009
31. Wykoff CC, Beasley N, Watson PH, Campo L, Chia SK, English R, et al. Expression of the hypoxia-inducible and tumor-associated carbonic anhydrases in ductal carcinoma in situ of the breast. Am J Pathol (2001) 158:1011-9. doi:10.1016/ S0002-9440(10)64048-5

32. Wykoff CC, Beasley NJ, Watson $\mathrm{PH}$, Turner KJ, Pastorek J, Sibtain A, et al. Hypoxia-inducible expression of tumor-associated carbonic anhydrases. Cancer Res (2000) 60:7075-83.

33. Ivanov SV, Kuzmin I, Wei $\mathrm{MH}$, Pack S, Geil L, Johnson BE, et al. Down-regulation of transmembrane carbonic anhydrases in renal cell carcinoma cell lines by wildtype von Hippel-Lindau transgenes. Proc Natl Acad Sci U S A (1998) 95:12596-601. doi:10.1073/ pnas.95.21.12596

34. Karumanchi SA, Jiang L, Knebelmann B, Stuart-Tilley AK, Alper SL, Sukhatme VP. VHL tumor suppressor regulates $\mathrm{Cl}-/ \mathrm{HCO} 3-$ exchange and $\mathrm{Na}+/ \mathrm{H}+$ exchange activities in renal carcinoma cells. Physiol Genomics (2001) 5:119-28.

35. Mekhail K, Gunaratnam L, Bonicalzi ME, Lee S. HIF activation by $\mathrm{pH}$-dependent nucleolar sequestration of VHL. Nat Cell Biol (2004) 6:642-7. doi:10.1038/ncb1144

36. Bockhorn M, Jain RK, Munn LL. Active versus passive mechanisms in metastasis: do cancer cells crawl into vessels, or are they pushed? Lancet Oncol (2007) 8:444-8. doi:10.1016/ S1470-2045(07)70140-7

37. Dawson MR, Duda DG, Fukumura D, Jain RK. VEGFR1-activityindependent metastasis formation. Nature (2009) 461:E4. doi:10.1038/ nature08254 discussion E5,

38. Bjornland K, Flatmark K, Pettersen S, Aaasen AO, Fodstad O, Maelandsmo GM. Matrix metalloproteinases participate in osteosarcoma invasion. J Surg Res (2005) 127:1516. doi:10.1016/j.jss.2004.12.016

39. Diresta GR, Nathan SS, Manoso MW, Casas-Ganem J, Wyatt C, Kubo $\mathrm{T}$, et al. Cell proliferation of cultured human cancer cells are affected by the elevated tumor pressures that exist in vivo. Ann Biomed Eng (2005) 33: 1270-80. doi:10.1007/s10439-0055732-9

40. Aung KZ, Pereira BP, Tan PH, Han HC, Nathan SS. Interstitial fluid pressure as an alternate regulator of angiogenesis independent of hypoxia driven HIF-1alpha in solid tumors. J Orthop Res (2012) 30:2038-45. doi:10.1002/jor.22154

41. Santini MT, Rainaldi G, Romano R, Ferrante A, Clemente S, Motta A, et al. MG-63 human osteosarcoma cells grown in monolayer and as three-dimensional tumor spheroids present a different metabolic profile: a (1)H NMR study. FEBS Lett (2004) 557:148-54. doi: 10.1016/S0014-5793(03)01466-2

42. Indovina P, Rainaldi G, Santini MT. Hypoxia increases adhesion and spreading of MG-63 threedimensional tumor spheroids. Anticancer Res (2008) 28:1013-22.

43. Lu Q, Lv G, Kim A, Ha JM, Kim S. Expression and clinical significance of extracellular matrix metalloproteinase inducer, EMMPRIN/CD147, in human osteosarcoma. Oncol Lett (2013) 5:201-7.

44. Sabile AA, Arlt MJ, Muff R, Bode B, Langsam B, Bertz J, et al. Cyr61 expression in osteosarcoma indicates poor prognosis and promotes intratibial growth and lung metastasis in mice. J Bone Miner Res (2012) 27:58-67. doi:10.1002/jbmr.535

45. Gvozdenovic A, Arlt MJ, Campanile C, Brennecke P, Husmann K, Li $\mathrm{Y}$, et al. CD44 enhances tumor formation and lung metastasis in experimental osteosarcoma and is an additional predictor for poor patient outcome. J Bone Miner Res (2013) 28:838-47. doi:10.1002/ jbmr.1817

46. Leask A, Abraham DJ. All in the CCN family: essential matricellular signaling modulators emerge from the bunker. J Cell Sci (2006) 119:4803-10. doi:10.1242/jcs.03270

47. Fromigue O, Hamidouche Z, Vaudin P, Lecanda F, Patino A, Barbry P, et al. CYR61 downregulation reduces osteosarcoma cell invasion, migration, and metastasis. J Bone Miner Res (2011) 26:1533-42. doi:10.1002/jbmr.343
48. Casciari JJ, Sotirchos SV, Sutherland RM. Variations in tumor cell growth rates and metabolism with oxygen concentration, glucose concentration, and extracellular $\mathrm{pH}$. J Cell Physiol (1992) 151:386-94. doi: 10.1002/jcp.1041510220

49. Ihnatko R, Kubes M, Takacova M, Sedlakova O, Sedlak J, Pastorek J, et al. Extracellular acidosis elevates carbonic anhydrase IX in human glioblastoma cells via transcriptional modulation that does not depend on hypoxia. Int $J$ Oncol (2006) 29:1025-33.

50. Pautke C, Schieker M, Tischer T, Kolk A, Neth P, Mutschler W, et al. Characterization of osteosarcoma cell lines MG-63, Saos-2 and U2 OS in comparison to human osteoblasts. Anticancer Res (2004) 24:3743-8.

51. Thiry A, Dogne JM, Masereel B, Supuran CT. Targeting tumorassociated carbonic anhydrase IX in cancer therapy. Trends Pharmacol Sci (2006) 27:566-73. doi:10.1016/ j.tips.2006.09.002

Conflict of Interest Statement: The authors declare that the research was conducted in the absence of any commercial or financial relationships that could be construed as a potential conflict of interest.

Received: 01 May 2013; accepted: 16 July 2013; published online: 29 July 2013.

Citation: Matsubara T, DiResta GR, Kakunaga S, Li D and Healey JH (2013) Additive influence of extracellular $\mathrm{pH}$, oxygen tension, and pressure on invasiveness and survival of human osteosar coma cells. Front. Oncol. 3:199. doi: 10.3389/fonc.2013.00199

This article was submitted to Frontiers in Pediatric Oncology, a specialty of Frontiers in Oncology.

Copyright (c) 2013 Matsubara, DiResta, Kakunaga, Li and Healey. This is an open-access article distributed under the terms of the Creative Commons Attribution License, which permits use, distribution and reproduction in other forums, provided the original authors and source are credited and subject to any copyright notices concerning any third-party graphics etc. 